\title{
Incidence rate of clinical bovine mastitis in selected smallholder dairy farms in Gondar town, Ethiopia
}

\author{
Gizat Almaw ${ }^{1 *}$, Wassie Molla, Achenef Melaku ${ }^{1}$ \\ ${ }^{1}$ Faculty of Veterinary Medicine, University of Gondar, Ethiopia \\ * Correspondent author: Gizat Almaw e-mail: tiwawyedegera@yahoo.com
}

\begin{abstract}
A study was conducted in Gondar town in six selected smallholder farms from August 2005 to January 2006 for six months to measure incidence rate of clinical bovine mastitis. Monitoring was performed by animal attendants of each farm after training and supervision of the monitoring activities and collection of data was performed by the researchers. Farmers identified cases of clinical mastitis on the basis of abnormalities in milk, in the udder or systemic abnormalities of the cow. A second or third case of clinical mastitis in the same lactation was considered a new case if at least 14 days had passed between the previous and the current case of clinical mastitis. The average incidence rate of clinical bovine mastitis at cow level was found to be 21.26 per 100 cow-years at risk ( 0.21 per cow-year at risk). Among the six farms, the highest incidence rate observed was 63.49 per 100 cow- years time and no case was recorded in two farms.
\end{abstract}

Keywords clinical mastitis. Ethiopia. Gondar town. incidence. smallholder dairy farms .

http://dx.doi.org/10.4314/evj.v16i1.8

\section{Introduction}

Ethiopia has the largest cattle population in Africa estimated at 44.32 million (CSA, 2004). But the per capita consumption of milk is only $19 \mathrm{~kg}$ per year (Redda, 2001) due to the low production level coupled with other factors. Cognizant of this fact, the Ministry of Agriculture and Rural Development has formulated a strategy to improve milk production through crossbreeding of the indigenous zebu with high-grade exotics (Holstein) (Asfaw, 1997). And because of this, there is an increase in the percentage of improved breeds in dairy cattle population of Ethiopia which are known to be more susceptible to most diseases including mastitis than the indigenous stock. According to Mekonnen Lemma et al. (2001), of the major diseases of crossbred cows in Addis Ababa milk shed, clinical mastitis was the second most frequent disease next to reproductive 
diseases, where 171 cows out of 556 were found to be affected. Mungube et al. (2005) estimated the economic losses from mastitis in the urban and periurban areas of Addis Ababa, Ethiopia, to be US $\$ 58$ per cow per lactation.

Several studies have been conducted in the past to estimate the incidence rate of clinical mastitis (IRCM) in Europe (Barkema et al., 1998; Peeler et al., 2000; Barnouin et al., 2005), North America (Sargeant et al., 1998) and Africa (Kivaria et al., 2006; Karimuribo et al., 2006). In Ethiopia, except some prevalence works on subclinical mastitis, very limited studies were conducted on the incidence of mastitis. This might be probably due to the difficulty to attend farms for a relatively longer period. A study conducted at Alemaya University Dairy Farm by Tefera (2001) for 6 years (from 1993 to 1998) revealed a clinical mastitis incidence of 34 cases per100 cows per year. There are no similar studies conducted in Amhara Regional State, except few unpublished reports. Therefore, this study was undertaken to measure the incidence rate of clinical bovine mastitis in selected dairy farms in Gondar town.

\section{Materials and methods}

\section{Study area}

The study was conducted in Gondar town, located $738 \mathrm{~km}$ away north of Addis Ababa, the capital city of Ethiopia. The total population of Gondar town is estimated to be 206,987 of which 98,085 are males and 108,902 females (CSA 2008). An Austrian assisted project named Integrated Livestock Development Project (ILDP) is working in the region since 1998 to improve farmers' livelihood. This project provides crossbred heifers to poor farmers and organized these smallholder farmers to form cooperatives. These cooperatives supply milk to Jantkel milk plant provided to them by the project. This plant also received milk from farmers in Gondar town. It produces maily pasteurized milk and to some extent cheese and butter and it is providing an oppurtunity for the dairy secotr to expand.

\section{Study population}

The study population was all lactating crossbred cows in different age and lactation number in smallholder farmers (having at least 5 lactating cows) in Gondar town. Their age and parity ranges from 2 to 11 years and one to eight, respectively. The feeding system included grazing and hay ad libitum with nug cake and Dashen Brewery byproduct supplementation. 


\section{Farm selection}

Farms having at least five lactating cows were considered in the study. Selection of farms was based on convenience and only farmers willing to cooperate throughout the study period were included in the study and six farms were selected. As most of the farmers in the town were having less than five lactating cows, those having five and above were included in the study while unwilling few remained.

\section{Incidence study}

The incidence study was conducted in government, non government (NGOs) and private dairy farms of Gondar town from August 2005 to January 2006 for six months. All lactating cows in selected farms were eligible for the study and followed until dry off or end of the study period. Follow up of the occurrence of clinical mastitic cases was conducted on daily basis by animal attendants, who were trained. The whole research process was supervised by the researchers. Animal attendants identified cases of clinical mastitis on the basis of abnormalities in milk, in the udder or systemic abnormalities of the cow. Cases subsequent to the firs case of clinical mastitis were considered as new, if at least 14 days had passed between any two cases of clinical mastitis (Riekerink et al., 2008).

A cow or a quarter shall be considered clinically sick for mastitis when abnormality is observed in milk (like the presence of flakes, clots, bloody or watery appearance), in the udder (like swelling, pain, hotness) or in the cow (systemic signs together with the above manifestations) (IDF, 1987).

\section{Data analysis}

The incidence rate (IR) of clinical mastitis was calculated according to the formula given inThrusfield (2005).

$$
\mathrm{IR}=\frac{\text { Number of new cases of disease that occur in a population during a particular period of time }}{\text { The sum, overall individuals, of the length of time at risk of developing disease }}
$$

The incidence rate of clinical mastitis (IRCM) was expressed as the reported number of CM episodes during the observation period per 100 cows per year at risk. 


\section{Results}

\section{Incidence rate}

Eight cows, from a total of 90 cows observed for 6 months, developed clinical mastitis (Table 1 ). The average incidence rate of clinical bovine mastitis at cow level was found to be 21.26 cases (23.24 standard deviation) per 100 cow-years at risk (0.21 per cow-year at risk) (Table 2 ).

Table 1 Number of cows developing clinical mastitis in all farms

\begin{tabular}{lllcc}
\hline $\begin{array}{l}\text { Cow } \\
\text { identification } \\
\text { (clinical cases) }\end{array}$ & $\begin{array}{l}\text { Period of } \\
\text { observation }\end{array}$ & $\begin{array}{l}\text { Time of development of } \\
\text { clinical mastitis after } \\
\text { beginning of observation }\end{array}$ & $\begin{array}{c}\text { Contribution } \\
\text { to cow-years at } \\
\text { risk }\end{array}$ & Farm \\
\hline 505 & 4 months & 4 month & 0.33 & $\mathrm{~A}$ \\
514 & 1 months & 1 month & 0.08 & $\mathrm{~A}$ \\
455 & 6 months & 6 month & 0.5 & $\mathrm{~A}$ \\
01 & 6 months & 6 months & 0.5 & $\mathrm{~B}$ \\
05 & 6 months & 6 months & 0.5 & $\mathrm{~B}$ \\
29312 & 3 months & 3 month & 0.25 & $\mathrm{C}$ \\
04 & 6 month & 6 month & 0.5 & $\mathrm{D}$ \\
027 & 4 months & 4 month & 0.33 & $\mathrm{D}$ \\
\hline
\end{tabular}

Among the six farms, the highest incidence rate (63.49 per 100 cow-years time) was observed in farm $\mathrm{D}$ and no case was recorded at $\mathrm{E}$ and $\mathrm{F}$ farms (Table 2).

Table 2 Incidence rate of clinical bovine mastitis by farm

\begin{tabular}{lcccc}
\hline Farm & $\begin{array}{c}\text { Number of } \\
\text { cows attended } \\
\text { (herd size) }\end{array}$ & $\begin{array}{c}\text { Total number of } \\
\text { clinical cases in } \\
\text { the farm }\end{array}$ & $\begin{array}{c}\text { Total cow-years } \\
\text { of the farm }\end{array}$ & $\begin{array}{c}\text { Incidence rate } \\
\text { per100 cow-years at } \\
\text { risk }\end{array}$ \\
\hline A & 38 & 3 & 15.61 & 19.21 \\
B & 19 & 2 & 8.23 & 24.30 \\
C & 13 & 1 & 4.87 & 20.53 \\
D & 8 & 2 & 3.15 & 63.49 \\
E & 5 & 0 & 2.24 & 0 \\
F & 7 & 0 & 3.41 & 0 \\
Total & 90 & 8 & 37.51 & $21.26 \mathrm{a}$ \\
\hline
\end{tabular}

a average incidence rate

\section{Discussion}

Clinical mastitis results in greater economic loss due to milk production loss, nonsaleable milk loss, veterinary service fees, medication cost, labor cost and culling especially when it occurs early in lactation. The incidence rates 
(21.26 cases per 100 cow-years) found in this study was lower compared to the previous work of Tefera (2001) in Ethiopia who reported 34 cases per 100 cows - years. A considerably high incidence rate compared to the present study was reported in other African countries. In Tanzania, in smallholders, Karimuribo et al. (2006) and Kivaria et al. (2006), reported 31.7 and 43.3 cow level clinical mastitis cases per 100 cow-years at risk, respectively. A lower incidence rate was reported in other studies. In Uruguay, an incidence rate of 1.2 cases per 100 cow-months at risk, which is equivalent to annual incidence rate of 14.4 cases per 100 cow-years at risk, was reported (Gianneechini et al., 2002). Peeler et al. (2000) in Great Britain and Riekerink et al. (2008) in Canada reported 22.8 and 23 mean incidence of clinical mastitis cases per 100 cows-years, respectively, which are in agreement to the finding of this study. This difference could most probably be attributed to the differences in the distribution of mastitis risk factors. Although the number of cows observed was small the highest incidence rate (63.49 per 100 cow- years time) in farm D in the present study could be due to poor milking and culling practice. There were cows with chronic mastitis and the awareness of milkers on segregation of affected cows and use of individual towels was very low.

\section{Conclusion}

The average incidence of clinical mastitis found in this study is low. However, there was high variability among farms. Therefore, there is a need for awareness creation among smallholder dairy farmers about the importance of clinical mastitis. Moreover, area specific and/or farm specific risk factors and the pathogens associated needs to be investigated.

\section{Acknowledgments}

The authors would like to thank University of Gondar, Research and Publication Office and Integrated Livestock Development (ILDP) for funding the project. We thank farm owners and animal attendants for their overall cooperation.

\section{References}

Asfaw, W., 1997. Livestock development policy in Ethiopia. In: Proceedings, Livestock Development Policies in Eastern and Southern Africa, CTA, OAU/IBAR, Ministy of Agriculture and Cooperatives, Swaziland, Paper presented in a seminar held on 28 July-August 1997 in Mbabane, Swaziland. 
Barkema, H. W., Schukken, Y. H., Lam, T, J.G. M., Beiboer, M.L., Wilmink, H., Bendictus, G. and Brand, A. 1998. Incidence of clinical mastitis in dairy herds grouped in three categories by bulk milk somatic cell counts. J Dairy Sci, 81, 411419 .

Barnouin, J., Bord, S., Bazin, S. and Chassagne, M., 2005. Dairy management practices associated with incidence rate of clinical mastitis in low somatic cell score herds in France. J Dairy Sci, 88, 3700-3709

Central Statistics Agency (CSA), 2008. Federal Democratic Republic of Ethiopia population census commission: Summary and statistical report of the 2007 population and housing census, Table 3.

Gianneechini, R., Concha, C., Rivero, R., Delucci, I and Moreno López, J., 2002. Occurrence of clinical and sub-clinical mastitis in dairy herds in the West Littoral Region in Uruguay. Acta Vet Scand, 43(4), 221-230.

International Dairy Federation (IDF), 1987. Bovine mastitis: definition and guidelines for diagnosis. Bulletin No. 211, $3-16$.

Karimuribo, E. D., Fitzpatrick, J.L., Bell, C.E., Swai, E.S., Kambarage, D.M., Ogden, N.H., Bryant, M.J. and French, N.P., 2006. Clinical and subclinical mastitis in smallholder dairy farms in Tanzania: risk, intervention and knowledge transfer. Prev. Vet. Med., 74, 84-98.

Kivaria, F.M., Noordhuizen, J. P.T.M., and Msami, H.M., 2006. Risk factors associated with incidence rate of clinical mastitis in smallholder dairy cows in Dar es Salaam Region, Tanzania. Vet J, doi:10.1016/j.tvj1.2006.01.009.

Lemma, M., Kassa, T. and Tegegne, A., 2001. Clinically manifested major health problems of crossbred dairy herds in urban and periurban production systems in the central highlands of Ethiopia. Trop. Anim. Hlth. Prod., 33, 85-89.

Mungube E. O., Tenhagen B.A., Regassa F., Kyule, M. N., Shiferaw, Y., Kassa, T. and Baumann M. P. O., 2005. Reduced milk production in udder quarters with subclinical mastitis and associated economic losses in crossbred dairy cows in Ethiopia. Trop. Anim. Hlth. Prod., 37, 1573-7438.

Peeler. E. J., Green. M. J., Fitzpatrick, J. L., Morgan. K. L. and Green, L. E., 2000. Risk factors associated with clinical mastitis in low somatic cell count British dairy herds. J Dairy Sci, 83, 2464-2472 
Redda, T., 2001. Small-scale milk marketing and processing in Ethiopia. In: Rangnekar, D. and Thorpe, W. (eds), Smallholder Dairy Production and Marketing Opportunities and Constraints. In: Proceedings of a South-South Workshop, NDDB, held on 13-16 March, Anand, India.

Riekkerink, R.G.M.O., Barkema, H.W., Kelton, D.F. and Scholl. T, 2008. Incidence rate of clinical mastitis on Canadian dairy farms. J Dairy Sci, 91, 1366-1377.

Sargeant, J. M., Scott, M. M., Leslie, K. E., Ireland, Bashiri, M. J. A., 1998. Clinical mastitis in dairy cattle in Ontario: frequency of occurrence and bacteriological isolates, Can. Vet. J., 39, 33-38.

Tefera, G., 2001. Prevalence of mastitis at Alemaya University Dairy Farm, J. Eth. Vet. Assoc., V, 17-21

Thrusfield, M., 2005. Veterinary Epidemiology. $3^{\text {rd }}$ ed., Blackwell Science Ltd. London, pp 182-198. 